\title{
Co-Administration of Subeffective Anxiolytic Doses of Diazepam and Hydroxyzine in Elevated Zero-Maze in Mice
}

\author{
Bijan Naghibi ${ }^{\otimes}$ and Farhoud Rayatnia ${ }^{2}$ \\ ${ }^{1}$ Neuroscience Research Center, Kerman University of Medical Sciences, Kerman, Iran \\ ${ }^{2}$ Pharmaceutics Research Center, School of Pharmacy, Kerman University of Medical Sciences, Kerman, Iran
}

Objective Benzodiazepines are from the most common drugs which are used for treatment of anxiety disorders. There are other drugs with antianxiety properties including antihistamines such as hydroxyzine, too. Body of evidence show that co-administration of two drugs which act through different mechanisms, makes the dose of each drug to be reduced, while preserving the desired effect with less adverse drug reactions. The aim of this study was to see whether co-administration of subeffective antianxiety doses of diazepam and hydroxyzine has any antianxiety effect in elevated zero-maze (EZM) in mice.

Methods To find the highest subeffective dose of each drug, different doses of hydroxyzine from 1.5 to $24 \mathrm{mg} / \mathrm{kg}$ and diazepam in doses of $0.25,0.5$ and $1 \mathrm{mg} / \mathrm{kg}$ were injected to male mice. Thirty minutes later, the animals were placed on EZM and various parameters of anxiety were recorded by a camera to assess later. After determination of subeffective antianxiety dose of the drugs, co-administration of hydroxyzine and diazepam was done and the anxiety parameters were measured.

Results In co-administration of $0.25 \mathrm{mg} / \mathrm{kg}$ of diazepam and $12 \mathrm{mg} / \mathrm{kg}$ hydroxyzine, as subeffective antianxiety doses of either drug, there were not any significant differences in main anxiety parameters, i.e., time spent in open areas and open area entries compared to control group. Hence, no anxiolytic effect was seen.

Conclusion It seems that subeffective doses of diazepam and hydroxyzine may not have any facilitating or synergistic effect on each other in antianxiety responses in mice.

Psychiatry Investig 2011;8:169-173

Key Words Anxiety, Diazepam, Elevated zero-maze, Hydroxyzine, Mice.

\section{INTRODUCTION}

Anxiety is a major symptom of many psychiatric disorders and almost always is present in surgical and serious medical conditions. In pharmacotherapy of anxiety, benzodiazepines and selective serotonin reuptake inhibitors are the mainly used drugs. Benzodiazepines are mostly useful in patients who have acute anxiety reactions due to their medical or psychiatric disease. Other drugs such as histaminic receptor-1 antagonists including hydroxyzine and diphenhydramine also have

Received: April 28, 2010 Revised: August 27, 2010

Accepted: August 30, 2010 Available online: October 5, 2010

$\triangle$ Correspondence: Bijan Naghibi, MD, PhD

Neuroscience Research Center, Kerman University of Medical Sciences, Jahad Blvd., Ebn Sina Ave., Kerman, Iran

Tel: +98-341-320-5011, Fax: +98-341-320-5003

E-mail: b_naghibi@kmu.ac.ir

(c) This is an Open Access article distributed under the terms of the Creative Commons Attribution Non-Commercial License (http://creativecommons.org/licenses/bync/3.0) which permits unrestricted non-commercial use, distribution, and reproduction in any medium, provided the original work is properly cited. antianxiety properties.

There are concerns about the potential for habituation, tolerance and abuse of benzodiazepines. In addition, these drugs can impair cognition and motor function, especially in the elderly, who may experience confusion, delirium and falls leading to fractures with lots of morbidity and mortality. ${ }^{1}$ Hence, reduction of these adverse effects would be of great concern. To achieve this goal, one of the strategies could be drug combination therapy, which is used frequently in situations where additive or synergistic responses are desired. In some instances, therapeutic effects are seen with submaximal doses of drugs when co-administered, with fewer side effects. ${ }^{2}$ In anxiolysis, there is also evidence of effective antianxiety activity in animals when subeffective doses of antianxiety drugs are co-administered. $^{3-5}$

In this study, we examined the anxiolytic effect of subeffective doses of diazepam and hydroxyzine in concert, to achieve the desired effective response in mice. 


\section{METHODS}

\section{Animals}

Male NMRI mice from a local breeding centre weighing 25$30 \mathrm{~g}$ were group-housed four per cage with controlled room temperature of 22-25 degrees. They were maintained on a 12 : 12 light-dark cycle and had access to food and water ad libitum. Tests were performed after one day of acclimatization to the above environment. All experiments were carried out between 09:00 and 13:00 h. Each mouse was tested once on the elevated zero-maze (EZM).

All procedures were conducted in accordance with the internationally accepted principles for laboratory animal use and care. The ethics code designated to this research from the ethical committee of Kerman Neuroscience Research Center was EC/KNRC/86-21.

\section{Elevated zero-maze}

The EZM has been designed in accordance with the original description of Shepherd et al. ${ }^{6}$ with a little modification. Briefly, the apparatus comprised of an annular track (width 5 $\mathrm{cm}$ ) with inner diameter of $40 \mathrm{~cm}$, divided into two opposite, open quadrants and two opposite, closed quadrants (height of the side walls was $15 \mathrm{~cm}$ ). The open parts have borders (height $2 \mathrm{~mm}$ ) for guiding the animal and preventing from falling. To measure the distance which animal travel on the apparatus, each open and closed area was divided into 10 equal parts by drawing fine lines.

All parts of the apparatus were made of wood, and the entire maze was elevated $40 \mathrm{~cm}$ above the floor. Testing was conducted in a quiet room that was illuminated with four ceiling-mounted, 40-watt, fluorescent light bulbs.

\section{Experimental design}

To begin a test session, mice were placed on the end of the open area facing the closed area designated as the starting point and were allowed to investigate the zero maze for a period of $5 \mathrm{~min}$. During this time, several anxiety-related variables were recorded by a webcam connected to a computer to analyze later. These parameters included the time spent in open area, the number of entries into open area, the number of head dippings over the border of open area, the number of stretch attend postures from closed area into the open area and the total distance traveled by each mouse on the EZM (by counting the number of fine lines on the apparatus crossed by animals, and turning the results into centimeter).

\section{Drug administration}

First, the anxiolytic dose of each drug was determined. Hydroxyzine (Darupakhsh, Iran) at the doses of 1.5, 3, 4.5, 6, 12,
15,18 and $24 \mathrm{mg} / \mathrm{kg}$ (8 groups) were dissolved in normal saline and administered intraperitoneally. For preparation of diazepam solution, one to two drops of Tween 80 (Merck, Germany) were added to normal saline and then diazepam (Chemidaru, Iran) was added and dissolved. The doses of diazepam used were $0.25,0.5$ and $1 \mathrm{mg} / \mathrm{kg}$ (subcutaneously). Thirty minutes after injections, the animals were placed on the EZM.

After determination of the highest sub-anxiolytic dose of either drug, both drugs were administered simultaneously by different routes (intraperitoneally and subcutaneously, respectively for hydroxyzine and diazepam), and the relevant solvents were injected to another group of animals as the control group through the same routes as the main drugs. Thirty minutes later, the animals were tested as previously described.

In all experiments, at least 6 animals were used in each group.

\section{Statistical analysis}

Data were analyzed using one-way analysis of variance, or where applicable, Kruskal-Wallis test. If there was a significant difference ( $\mathrm{p}<0.05)$, Holm-Sidak or Dunn's methods were used, respectively. The outliers were excluded by SmirnovGravus' rejection test. The statistical software used was Sigmastat 3.1.

\section{RESULTS}

As is seen in Table 1, different doses of hydroxyzine, did not make any significant differences in the number of entries into open area, the time spent in open area, the number of head dippings and the number of stretch attend postures compared to the control group. The total distance traveled in the three higher doses $(15,18$ and $24 \mathrm{mg} / \mathrm{kg})$ was significantly less than the control group ( $\mathrm{p}<0.01, \mathrm{p}<0.001$ and $\mathrm{p}<0.001$, respectively). In addition, animals in these three groups were motionless in a crouching position for rather a long period of time.

In animals which received $0.5 \mathrm{mg} / \mathrm{kg}$ diazepam (Table 2), there was a significant difference in the number of entries into open area and the time spent in open area compared to the control group ( $\mathrm{p}<0.01$ and $\mathrm{p}<0.001$, respectively). Animals that received the highest dose $(1 \mathrm{mg} / \mathrm{kg})$ showed a significant increase in the time spent in open area and the number of stretch attend postures compared to the control animals $(\mathrm{p}<0.01$ and $\mathrm{p}<$ 0.05 , respectively).

Animals which received both hydroxyzine $(12 \mathrm{mg} / \mathrm{kg})$ and diazepam $(0.25 \mathrm{mg} / \mathrm{kg})$ did not show any differences in the number of entries into open area, the time spent in open area and the total distance traveled compared to their controls (Table 3). However, the number of head dippings was significantly less $(\mathrm{p}<0.05)$ and the number of stretch attend postures was significantly more than the control group $(\mathrm{p}<0.05)$. 


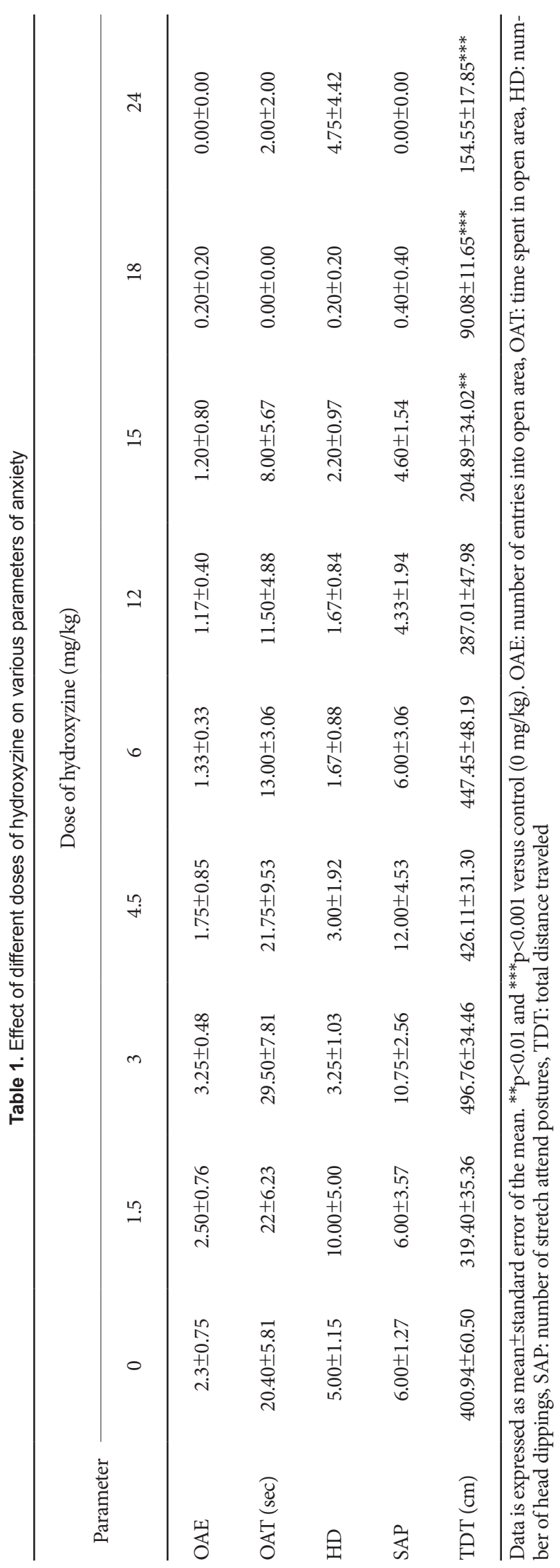

\section{DISCUSSION}

In this study, the effect of co-administration of subeffective doses of two antianxiety agents, hydroxyzine and diazepam, that exert their anxiolytic effect through different mechanisms, was studied. First, the lowest antianxiety dose of each drug was determined. In the case of hydroxyzine, Gladney et al. ${ }^{7}$ had investigated the anxiolytic effect of different doses of hydroxyzine $(1,4,7$ and $10 \mathrm{mg} / \mathrm{kg})$ in mice, and only $1 \mathrm{mg} / \mathrm{kg}$ of hydroxyzine had shown the antianxiety property. Hence, we started with the dose of $1.5 \mathrm{mg} / \mathrm{kg}$ which seemed to be anxiolytic according to that study; however, this dose did not show any antianxiety effect. Then the higher doses (3, 4.5, 6 and $12 \mathrm{mg} / \mathrm{kg}$ ) were studied consecutively, and all of them showed no anxiolytic activity. After doubling the last dose, i.e., administration of $24 \mathrm{mg} / \mathrm{kg}$, the animals' locomotor activity, as was evident by the total distance traveled, was declined dramatically and the mice appeared sleepy. Then the mean dose between 12 and $24 \mathrm{mg} / \mathrm{kg}$ (i.e., $18 \mathrm{mg} / \mathrm{kg}$ ) was chosen and the experiment repeated. A reduction in mice locomotor activity and drowsiness was seen again. When the mean dose between 18 and 12 was selected, the same results with 24 and $18 \mathrm{mg} / \mathrm{kg}$ were observed (Table 1), without any significant changes in other anxiety parameters.

In humans, hydroxyzine exerts its antianxiety effect at doses of about $400 \mathrm{mg} /$ day, which lead to marked sedation. ${ }^{1}$ It could be concluded that the anxiolytic and the hypnotic doses of hydroxyzine are very close to each other. Hence, in our study, the doses of 15, 18 and $24 \mathrm{mg} / \mathrm{kg}$ of hydroxyzine which made animals sleepy, were supposed to be anxiolytic, which was opposite to what Gladney et al. ${ }^{7}$ had reported, but close to the results of some other studies which indicated that the anxiolytic dose of hydroxyzine in rats is at least $8 \mathrm{mg} / \mathrm{kg}{ }^{8,9}$ and in mice should be greater than $4 \mathrm{mg} / \mathrm{kg}{ }^{10}$ Consequently, the dose of 12 $\mathrm{mg} / \mathrm{kg}$ was determined as the highest dose which did not have an antianxiety effect, and was selected as the subeffective dose for the rest of the experiment.

For determination of the subeffective dose of diazepam, the experiment began with $1 \mathrm{mg} / \mathrm{kg}$ diazepam, which was proved to be anxiolytic in mice in many studies ${ }^{11-13}$ as well as our previous experiments. This dose was proved to be antianxiety, since the time spent in open area was increased and the number of stretch attend postures was decreased significantly compared to controls (Table 2). Then this dose was halved and the experiment was done by $0.5 \mathrm{mg} / \mathrm{kg}$ diazepam. The time spent in open area and the number of entries into open area was increased significantly compared to the control group, so this dose was also anxiolytic (as in other previous studies ${ }^{14,15}$ ). There were no changes in anxiety parameters when diazepam at the dose of $0.25 \mathrm{mg} / \mathrm{kg}$ was tested. Hence, this dose was selected as the 
Table 2. Effect of different doses of diazepam on various parameters of anxiety

\begin{tabular}{lcccc}
\hline \multirow{2}{*}{ Parameter } & \multicolumn{4}{c}{ Dose of diazepam $(\mathrm{mg} / \mathrm{kg})$} \\
\cline { 2 - 5 } & 0 & 0.25 & $3.33 \pm 0.88^{* *}$ & $2.40 \pm 0.25$ \\
OAE & $1.17 \pm 0.48$ & $0.50 \pm 0.29$ & $34.33 \pm 3.19^{* * *}$ & $21.20 \pm 3.68^{* *}$ \\
OAT $(\mathrm{sec})$ & $7.33 \pm 2.89$ & $8.67 \pm 2.93$ & $0.33 \pm 0.33$ & $2.00 \pm 0.93$ \\
HD & $0.83 \pm 0.48$ & $2.20 \pm 1.43$ & $4.67 \pm 0.88$ & $6.17 \pm 1.62^{*}$ \\
SAP & $2.17 \pm 0.70$ & $0.40 \pm 0.25$ & $456.28 \pm 38.27$ & $480.42 \pm 55.87$ \\
TDT $(\mathrm{cm})$ & $328.52 \pm 20.97$ & $284.37 \pm 61.34$ & \\
\hline
\end{tabular}

Data is expressed as mean \pm standard error of the mean. ${ }^{*} \mathrm{p}<0.05,{ }^{* *} \mathrm{p}<0.01$ and ${ }^{* * *} \mathrm{p}<0.001$ versus control $(0 \mathrm{mg} / \mathrm{kg})$. OAE: number of entries into open area, OAT: time spent in open area, HD: number of head dippings, SAP: number of stretch attend postures, TDT: total distance traveled

Table 3. Effect of co-administration of $12 \mathrm{mg} / \mathrm{kg}$ hydroxyzine and $0.25 \mathrm{mg} / \mathrm{kg}$ diazepam on various parameters of anxiety

\begin{tabular}{lcc}
\hline \multirow{2}{*}{ Parameter } & \multicolumn{2}{c}{ Treatment groups } \\
\cline { 2 - 3 } & $\begin{array}{c}\text { Co-administration of } \\
\text { diazepam and hydroxyzine }\end{array}$ & Control \\
\hline OAE & $2.00 \pm 0.71$ & $2.63 \pm 1.31$ \\
OAT $(\mathrm{sec})$ & $21.33 \pm 6.48$ & $21.38 \pm 9.27$ \\
HD & $4.11 \pm 1.16^{*}$ & $0.88 \pm 0.35$ \\
SAP & $5.38 \pm 1.41^{*}$ & $1.38 \pm 0.60$ \\
TDT $(\mathrm{cm})$ & $358.77 \pm 33.98$ & $285.91 \pm 42.15$ \\
\hline
\end{tabular}

Data is expressed as mean \pm standard error of the mean. ${ }^{*} \mathrm{p}<0.05$ versus control. OAE: number of entries into open area, OAT: time spent in open area, HD: number of head dippings, SAP: number of stretch attend postures, TDT: total distance traveled

subeffective dose of diazepam.

The main part of the experiment was done by administration of $12 \mathrm{mg} / \mathrm{kg}$ hydroxyzine and $0.25 \mathrm{mg} / \mathrm{kg}$ diazepam simultaneously. The two major anxiety parameters, the time spent in open area and the number of entries into open area did not change when both drugs were co-administered, indicated on absence of anxiolysis. Meanwhile, both the number of head dippings and the number of stretch attend postures were increased significantly compared to the control group. Although an increase in the number of head dippings indicates in anxiolysis, the number of stretch attend postures increment shows an anxiogenic effect. Hence, it seems a paradoxical result has been obtained. However, these are minor anxiety parameters and the number of entries into open area and the time spent in open area are the most reported and putative anxiety indices, and overshadow the results of the number of head dippings and the number of stretch attend postures. Co-administration of hydroxyzine and diazepam had no effect on locomotor activity of mice as was evident by the lack of significant changes in the total distance traveled (Table 3). From all above, it seems that at subeffective doses, co-administration of these two agents did not have an antianxiety property in mice. In the work of Gladney et al., ${ }^{7}$ concurrent administration of hydroxyzine and chloral hydrate did not result in addi- tive or synergistic anxiolytic effect, either. However, there are reports that the co-administration of subeffective doses of some drugs does have anxiolytic properties. Xu et al. ${ }^{3}$ have reported that the subeffective dose of baicalin, a naturally occurring flavonoid with anxiolytic-like effect, has additive response with the subeffective dose of diazepam. Similarly, concurrent administration of subeffective doses of Withania somnifera with antianxiety activity and ethanol, ${ }^{16}$ subeffective doses of magnesium and diazepam or chlordiazepoxide, ${ }^{5}$ Naloxone, which does not have the antianxiety property by itself, used with subeffective doses of diazepam, chlordiazepoxide and buspirone, ${ }^{17}$ resulted in additive or synergistic effects.

There are also some reports that in anxiolysis, different systems can have facilitating effects on each other. Serotonergic system, through serotonin $5-\mathrm{HT}_{2 \mathrm{~A}}$ receptors, has shown to facilitate the action of $\gamma$-aminobutyric acid (GABA) in alleviating anxiety. ${ }^{4}$ Hydroxyzine, in addition to its antihistaminic properties, has antimuscarinic effects, ${ }^{18,19}$ which may be responsible for its sedative effects, ${ }^{20}$ although its antianxiety effect is also attributed to histamine-1 receptor blockage. ${ }^{19}$ Hence both antihistaminic and anticholinergic properties of hydroxyzine, alone or in combination, may be involved in its sedative effect. Although it is clear that the concurrent use of therapeutic doses of hydroxyzine and other central nervous system depressants produces an additive effect in sedation, which can even lead to the impairment of motor function; ${ }^{20}$ however, using subeffective doses of diazepam and hydroxyzine together may not have the facilitating effect on each other. According to our results, it seems that neither antihistaminic, nor antimuscarinic properties of hydroxyzine have facilitatory effect on GABAergic system in anxiolysis in mice.

\section{Acknowledgments}

This work was financially supported by grant number 86-21/A from Neuroscience Research Center of Kerman University of Medical Sciences.

\section{REFERENCES}

1. Baldessarini RJ. Drug Therapy of Depression and Anxiety Disorders. In: Brunton LL, Lazo JS, Parker KL, Editors. Goodman and Gilman's the Pharmacological Basis of Therapeutics. 11th ed. New York: McGraw- 
Hill, 2006, p.429-459.

2. Oates JA. The Science of Drug Therapy. In: Brunton LL, Lazo JS, Parker KL, Editors. Goodman and Gilman's the Pharmacological Basis of Therapeutics. 11th ed. New York: McGraw-Hill, 2006, p.117-136.

3. Xu Z, Wang F, Tsang SY, Ho KH, Zheng H, Yuen CT, et al. AnxiolyticLike Effect of baicalin and its additivity with other anxiolytics. Planta Med 2006;72:189-192.

4. Massé F, Nic Dhonnchadha BA, Hascoët M, Bourin M. Anxiolytic-like effect of 5-HT(2) ligands and benzodiazepines co-administration: comparison of two animal models of anxiety (the four-plate test and the elevated plus maze). Behav Brain Res 2007;177:214-226.

5. Poleszak E. Benzodiazepine/GABA(A) receptors are involved in magnesium-induced anxiolytic-like behavior in mice. Pharmacol Rep 2008; 60:483-489.

6. Shepherd JK, Grewal SS, Fletcher A, Bill DJ, Dourish CT. Behavioural and pharmacological characterisation of the elevated "zero-maze" as an animal model of anxiety. Psychopharmacology (Berl) 1994;116:56-64.

7. Gladney M, Stanley RT, Hendricks SE. Anxiolytic activity of chloral hydrate and hydroxyzine. Pediatr Dent 1994;16:183-189.

8. Yamamoto T, Kumasaka Y, Ueki S. Behavioral analysis of zopiclone on the basis of their discriminative stimulus properties in the rat. Jpn J Pharmacol 1989;51:337-345.

9. Martin P, Guillou N, Lacroix P, Billardon M. [Effects of co-administration of an antidepressant and an anxiolytic drug in the "learned helplessness" paradigm: importance of hydroxyzine.] Encephale 1996;22:270279 .

10. Frances $\mathrm{H}$, Lienard C. Isolation-induced social behavioral deficit test: effect of tranquillizing drugs. Pharmacol Biochem Behav 1989;34:293-296.

11. Consoli D, Leggio GM, Mazzola C, Micale V, Drago F. Behavioral effects of the $\beta 3$ adrenoceptor agonist SR58611A: is it the putative prototype of a new class of antidepressant/anxiolytic drugs? Eur J Pharmacol 2007;573:139-147.
12. Silva MI, de Aquino Neto MR, Teixeira Neto PF, Moura BA, do Amaral JF, de Sousa DP, et al. Central nervous system activity of acute administration of isopulegol in mice. Pharmacol Biochem Behav 2007; 88:141-147.

13. Luuk H, Plaas M, Raud S, Innos J, Sütt S, Lasner H, et al. Wfs1-deficient mice display impaired behavioural adaptation in stressful environment. Behav Brain Res 2009;198:334-345.

14. Raud S, Rünkorg K, Veraksits A, Reimets A, Nelovkov A, Abramov U, et al. Targeted mutation of CCK2 receptor gene modifies the behavioural effects of diazepam in female mice. Psychopharmacology (Berl) 2003; 168:417-425.

15. Ognibene E, Bovicelli P, Adriani W, Saso L, Laviola G. Behavioral effects of 6-bromoflavanone and 5-methoxy-6,8-dibromoflavanone as anxiolytic compounds. Prog Neuropsychopharmacol Biol Psychiatry 2008; 32:128-134.

16. Gupta GL, Rana AC. Effect of Withania somnifera Dunal in ethanol-induced anxiolysis and withdrawal anxiety in rats. Indian J Exp Biol 2008; 46:470-475.

17. Belzung C, Agmo A. Naloxone potentiates the effects of subeffective doses of anxiolytic agents in mice. Eur J Pharmacol 1997;323:133-136.

18. Pasricha PJ. Treatment of Disorders of Bowel Motility and Water Flux; Antiemetics; Agents Used in Biliary and Pancreatic Disease. In: Brunton LL, Lazo JS, Parker KL, Editors. Goodman and Gilman's the Pharmacological Basis of Therapeutics. 11th ed. New York: McGraw-Hill, 2006, p.983-1008.

19. Katzung BG. Histamine, Serotonin, \& the Ergot Alkaloids. In: Katzung BG, editor. Basic \& Clinical Pharmacology. 10th ed. New York: McGrawHill, 2007, p.255-276.

20. Skidgel RA, Erdos EG. Histamine, Bradykinin and Their Antagonists. In: Brunton LL, Lazo JS, Parker KL, Editors. Goodman and Gilman's the Pharmacological Basis of Therapeutics. 11th ed. New York: McGraw-Hill, 2006, p.629-651. 